\title{
The genus Portulaca as a suitable model to study the mechanisms of plant tolerance to drought and salinity
}

\author{
Orsolya Borsai ${ }^{1,2}$, Mohamad Al Hassan ${ }^{2,4}$, Monica Boscaiu ${ }^{3}$, Radu E. Sestras ${ }^{1}$ and Oscar Vicente ${ }^{2 *}$
}

\begin{abstract}
Drought and soil salinity are at present the major factors responsible for the global reduction of crop yields, and the problem will become more severe in the coming decades because of climate change effects. The most promising strategy to achieve the increased agricultural production that will be required to meet food demands worldwide will be based on the enhancement of crop stress tolerance, by both, traditional breeding and genetic engineering. This, in turn, requires a deep understanding of the mechanisms of tolerance which, although based on a conserved set of basic responses, vary widely among plant species. Therefore, the use of different plant models to investigate these mechanisms appears to be a sensible approach. The genus Portulaca could be a suitable model to carry out these studies, as some of its taxa have been described as tolerant to drought and/or salinity. Information on relevant mechanisms of tolerance to salt and water stress can be obtained by correlating the activation of specific defence pathways with the relative stress resistance of the investigated species. Also, species of the genus could be economically attractive as 'new' crops for 'saline' and 'arid', sustainable agriculture, as medicinal plants, highly nutritious vegetable crops and ornamentals.
\end{abstract}

Keywords: Climate change, new crops, purslane, salt stress, water deficit

'Faculty of Horticulture, University of Agricultural Sciences and Veterinary Medicine, Cluj-Napoca, Romania

Institute of Plant Molecular and Cellular Biology (IBMCP, UPV-CSIC), Universitat Politècnica de València, Valencia, Spain; corresponding author: ovicente@ibmcp. upv.es

${ }^{3}$ Mediterranean Agroforestry Institute (IAM, UPV), Universitat Politècnica de València, Valencia, Spain

${ }^{4}$ present address: The New Zealand Institute for Plant \& Food Research, Auckland, New Zealand

${ }^{*}$ Corresponding author: O. Vicente E-mail: ovicente@ibmcp.upv.es

DOI: 10.2478/ebtj-2018-0014

(C) 2018 Authors. This work was licensed under the Creative Commons AttributionNonCommercial-NoDerivs 3.0 License.

\section{Introduction}

In the context of climate change and its effects, including increases in global temperature, scarcity of water resources for agriculture (lower rainfall, higher evaporation and evapotranspiration, reduced groundwater recharge) and salinisation of the soil in fields cultivated under irrigation, abiotic stress is already limiting food production through reduction of crop yields. This problem will become even more severe as the area affected by climate change-induced desertification extends. For example, long periods of intense droughts suffered in the Sahel region of Africa during the last decades have caused a substantial decrease in food production $(1,2)$. Crop yields were also significantly reduced by drought in the U.S. several times in the previous century, from $30 \%$ to more than $50 \%$, mostly affecting maize production in the Midwestern States - in the so-called 'corn belt' - with the most severe droughts registered in the 1930s or in 1988 (3-5). Progressive 'secondary' salinisation of irrigated land, due to the continuous accumulation in the soil of toxic ions present in irrigation water, also limits agricultural production, contributing to the enormous challenge of feeding the world's growing population in the next decades. At present, more than 800 million hectares of agricultural land worldwide is affected by salinity, to a greater or lesser degree (6) and it has been predicted that before 2050 salinity will seriously affect $30 \%$ of the available arable land area and about $50 \%$ by 2100 (7). Therefore, enhancing drought and salt stress tolerance of our major crops (for food supply and other applications) using both, traditional breeding and genetic engineering, should be a research priority in plant biotechnology in the coming years. 
The vast majority of terrestrial plants, including all major crops, are glycophytes or salt-sensitive plants. Yet, a small percentage of angiosperm species (less than 1\%) belonging to different genera and families, are adapted to saline environments and can complete their life cycle in habitats with soil salinity equivalent to $200 \mathrm{mM} \mathrm{NaCl}$ or more; these plants are defined as halophytes (8). Since plants show a continuous range of tolerance, from species extremely sensitive to salt to other highly tolerant, there are many taxa that, although cannot be considered as halophytes according to this definition, are nevertheless relatively resistant to salinity when compared to our present major crops; they may include some minor crops or potential crop species not cultivated commercially at present. Similarly, other species may be interesting as potential crops because of their relatively high tolerance to drought.

Plant adaptation and tolerance to abiotic stresses are regulated by complex molecular networks. Tolerance to water deficit, soil salinity and other environmental stress conditions involves responsive mechanisms to re-establish homeostasis, to maintain osmotic balance, to repair damaged proteins and membranes and to activate antioxidant systems - as all these stressful conditions cause oxidative stress as a secondary effect. While plant resistance to pathogens (biotic stress) is generally dependent on monogenic traits, the mechanisms of abiotic stress tolerance are multigenic and more complex, which makes them more difficult to investigate and, eventually, to control and manipulate (7). Paradoxically, most studies on the responses of plants to abiotic stresses and the mechanisms of tolerance have been performed using stress-sensitive species, especially the model plant Arabidopsis thaliana (9) or some crops such as Oryza sativa (10), Nicotiana tabacum (11), or Solanum lycopersicum (12). All plant species appear to have built-in capabilities for stress perception, signalling and response, although they clearly differ in their sensitivity and reaction to the decrease in water potential caused by drought, high salinity, low temperature or other abiotic stresses. Differences between sensitive and tolerant species seem to be of a quantitative rather than of a qualitative nature, resulting from changes in the expression patterns of a primary, conserved set of genes $(9,13,14)$.

The domestication of wild halophytes (and other relatively salt-tolerant species) could be considered a substitute retrieval practice for plant breeders offering viable alternatives for saline agriculture. The sustainable use of salt-tolerant species has multiple purposes as food and feed crops, as a source of renewable energy (biofuels: bioethanol and biodiesel) (15), as raw material for different industrial uses and also for regeneration of degraded areas. Another advantage of saline agriculture is that commercial cultivation of halophytes might be combined with aquaculture of sea fishes, providing a broader range of products to the food market (16). A few scientific reports have been published emphasising the economic potential of salt-tolerant plants in agriculture as a source of food, oils, fibres (17), pharmaceuticals or with environmental potential for protection and biodiversity conservation. These include, for example, potential vegetable crops and grain crops such as: Sali- cornia europaea (18); Aster tripolium, Sesuvium portulacastrum (19); Inula crithmoides (20, 21); Chenopodium quinoa (22) and Distichlis palmeri (23); oilseeds such as Salicornia bigelovii (24) and Suaeda fruticosa (25) and medicinal plants: Helianthus tuberosus (26), Achillea mellifolium, Verbena officinalis (27).

Cultivation of drought and/or salt-tolerant plants in marginal lands, arid zones or salinised cropland under rainfed conditions or using low-quality, salinised water for irrigation, will contribute to food production (apart from other economically interesting uses), through a more efficient use of limited resources such as fertile land and good-quality irrigation water, since they will not compete with conventional crops, which cannot grow under those conditions. These 'new' crops could include some species and cultivars of the genus Portulaca, which appear to have a relatively high resistance to drought and soil salinity, as compared to most standard crops (28).

This review attempts to give an overview of the most general responses of plants to abiotic stress, especially to drought and salinity, with focus on Portulaca taxa (but including also other examples), to summarise what is known for this genus. Although the information available is still limited, there are data indicating that Portulaca species and cultivars show variable levels of resistance to salinity and water deficit. For this reason, Portulaca can be considered as a suitable model to carry out comparative studies on their stress responses; this will, in turn, contribute to improving our knowledge on the general mechanisms of abiotic stress tolerance in plants.

\section{The Genus Portulaca: Potential as Biological Model and Economic Interest}

The genus Portulaca includes about 100 species, with a wide distribution, predominantly in tropical and subtropical regions, and a high morphological variability (29-31). Studies in different areas - taxonomy, ecology, physiology, biochemistry or genetics - have been performed on Portulaca species, including also the assessment of the genetic variability within the genus. Evolutionary relationships of Portulaca taxa were addressed through a BEAST ['Bayesian evolutionary analysis by sampling trees' (32)] analysis of a combined matrix of molecular markers (ITS) and several specific gene sequences; the obtained dendrogram was then correlated with the known taxonomy, morphology, biogeography, and chromosome number variation of the genus (33). Responses of Portulaca to abiotic stresses, such as elevated temperatures, water deficit or high salinity, have also been investigated by different authors (34-36). Even though most of these studies have been carried out in a single species, $P$. oleracea, it has been established that this and other taxa of the genus are relatively resistant to drought and/or salt stress, as compared to the major crops $(35,37)$.

The accumulated information on Portulaca species, together with the relatively easy handling of the plants, their size and short life cycle - eight to ten weeks under optimal conditions - would suggest that this genus can be used as a suitable research model in plant biology. In general terms, obviously, Portulaca cannot compete with other well-established model spe- 
cies, such as Arabidopsis thaliana and several major crops, for which many more data and resources are available. Yet, studies on abiotic stress tolerance in plants require the use of different models, as the responses to stress that are relevant for tolerance vary between species. Considering that Portulaca provides a large number of species and cultivars, with a common genetic background but - presumably - a wide range of tolerance degrees to water and/or salt stress, this genus represents an attractive model for these specific studies. Comparative analyses of the mechanisms activated in response to controlled stress treatments in different taxa, and correlation with their relative levels of stress resistance should allow identifying the responses that are most important for tolerance in this genus, thus complementing information obtained from studies in other genera.

In addition to their possible use for basic research, many Portulaca species are also interesting from an economic point of view, as potential 'new' crops for sustainable agriculture. Common purslane (P. oleracea) is a nutritious herb with a high content of 'healthy' antioxidant compounds and essential nutrients, such as $\alpha$-linolenic acid, omega- 3 and omega- 6 fatty acids, ascorbic acid, glutathione, $a$-tocopherol and $\beta$-carotene (38). There are few vegetable sources rich in $\omega-3$ fatty acids; this, together with the species' relatively high salt tolerance, explains the growing interest to promote purslane as a new vegetable crop (35). In Chinese folklore, P. oleracea is known as 'vegetable for a long life' with a long history of use as both, an edible plant and traditional herbal medicine. It has been used for alleviating pain and swelling and has been attributed antibacterial, antiviral, antidiabetic or enhancing immunity properties (39). It has been recently suggested that $P$. oleracea may help to reduce the occurrence of cancer and cardiovascular diseases (40).

Plants of the Portulacaceae family include also cash crop species that can tolerate moderate to high salt stress, producing profitable amounts of dry mass even at high salinities (41, 42). Moreover, they include as well several ornamental species, such as Portulaca grandiflora, P. umbraticola, P. villosa or P. halimoides, which are highly appreciated for their wide range of flower colours, type and size, and their potential use in garden design even in unfavourable environmental conditions. The availability of many commercial cultivars of these ornamental species increases the genetic variability of the genus as a whole and facilitate the comparative studies mentioned above.

\section{Plant Responses to Salt and Water Stress}

An unfavourable environment due to salinity, drought or other stressful conditions induces a complex set of responses in plants, which can sense the stress and react activating many different mechanisms, at the physiological, biochemical and molecular levels that may (or may not) enable their survival (43-45). Plants have even the capacity to 'remember' past exposure to abiotic stresses, modifying their responses when subjected again to the same stress so that the adverse conditions can be more easily overcome (46). The outcome of these responses depends on different factors, such as the type, intensity and duration of the applied stress, the combination of different stressful conditions, the tissue or organ of the plant affected and, obviously, the intrinsic level of tolerance of the species. It is also important the phase of the plant's life cycle, with younger individuals being generally more sensitive to stress than older plants (e.g. 47). As mentioned above, all plants share the same basic responses to abiotic stress. However, information about the molecular mechanisms relevant for the tolerance to a specific type of stress of a given species - or group of related taxa - is still insufficient.

\section{Salt and water stress responses during seed germination}

Germination of seeds and early vegetative growth are in general the developmental stages most sensitive to abiotic stress and, therefore, a bottleneck in the plant life cycle under stress conditions. The responses to salt and water stress at this very early stage of development have been already investigated in different Portulaca taxa - although most studies have been carried out on common purslane (P. oleracea) - showing the progressive inhibition of seed germination as the intensity of the stress increases; high salt concentrations and lack of water both cause osmotic stress on germinating seeds and early seedlings but, in general, at the same osmotic potentials salinity has a more deleterious effect than water deficit, producing a stronger inhibition of germination, as reflected by lower final germination percentages and longer germination times (28,37,48-51). Regarding the stress-induced inhibition of seed germination, Portulaca species are not different from most other plants, which show similar responses to water deficit or soil salinity, although with clear differences between species in their relative tolerance. This has been shown, for example, in Asparagus officinalis and Solanum lycopersicum (52). Likewise, in a study on the salt tolerance at the seed germination stage of Ocimum basilicum, Eruca sativa and Petroselinum hortense (53) it was found that parsley was the most sensitive of the three species, showing the strongest inhibition of germination with increasing salt concentrations.

In some ornamental plant species such as Ageratum mexicanum (54) and Tagetes patula $(54,55)$, increasing the substrate salinity led to the inhibition of plant growth at the highest salt concentration tested. Catharanthus roseus, when subjected to salt treatments showed delayed germination at low salinity levels and completed inhibition at high salt concentrations (56, 57). Similarly, seed germination in Limonium cossonianum was also largely affected under conditions of high salinity (58). Despite the examples above and many other reports on other species supporting this general behaviour, seed germination of some halophytes (salt-tolerant plants) is enhanced to different degrees at low or moderate salinity levels and inhibited only at higher salt concentrations (e.g. 59).

\section{Growth inhibition as a general response to drought and salinity}

The most widespread and rapid response of plants to any type of stress is inhibition of growth as they redirect their resources - assimilates, metabolic precursors, energy - from primary 
metabolism and biomass accumulation to the activation of specific defence mechanisms (60-63). Therefore, the most straightforward and convenient way to assess the effects of drought and salt treatments on plants is based on the quantification of the degree of stress-induced growth inhibition. This can be done by determining different growth parameters (depending on the species), such as plant height or stem length, number of leaves, total leaf area, number of flowers or fresh and dry weight of the treated plants, in relation to the untreated controls.

This kind of measurements has been performed on seedlings of 12 common purslanes and cuttings of 13 ornamental purslane accessions treated with increasing $\mathrm{NaCl}$ concentrations, providing salinities of $0,10,20,30$ and $40 \mathrm{dS} \mathrm{m}^{-1}$ (57). It was found that the height of the salt-treated plants was slightly (but significantly) reduced in relation to the corresponding non-stressed controls, in a concentration-dependent manner, from $7 \%$ at the lowest salinity tested to about $20 \%$ at the highest. A similar pattern was observed regarding the relative changes in the number of leaves upon salt treatment of the plants; these numbers, which varied in the different purslane accessions, were generally reduced as compared to those of the corresponding controls in parallel with the increase in external salinity (64). According to the measured growth parameters, differences in their relative salt tolerance were detected among the selected purslane accessions.

As for the number of leaves, the number of flowers of the studied purslane taxa also differed from one accession to another in untreated plants and decreased in all of them with increasing salt concentrations although, here again, with quantitative differences between accessions. Among all the investigated morphological traits, flowering appeared to be the most affected by salinity: at $40 \mathrm{dS} \mathrm{m} \mathrm{m}^{-1}$, most accessions showed a reduction in flower number of more than $90 \%$ as compared to the corresponding controls or produced no flowers at all (64). Previous reports also revealed delayed flowering and fruiting as a response to stress in other ornamental and crop species, such as Iris hexagona (65), Cakile edentula (66) and Sporobolus virginicus (67).

Plant fresh weight and dry weight (or water content) are the parameters most often used to quantify the degree of stress-induced inhibition of growth. Their measurement, however, requires uprooting and killing the plant, contrary to merely determining the height of the plant or counting the number of leaves or flowers; both, fresh and dry weight are affected by drought and salinity (56). The plants of the tested Portulaca accessions differed in size (at the same developmental stage), and therefore in fresh and dry weight, before being submitted to the salt stress treatment; yet in all taxa biomass accumulation was reduced with respect to the corresponding controls at the end of the experiments, in a concentration-dependent manner; that is, the most substantial inhibition of growth was detected in the presence of the highest salt concentration tested (64).

The aforementioned changes observed in plants as a response to salt or water deficit treatments are partly due to the shedding of old leaves while maintaining the younger ones (37,
68), as well as to the reduction of the area of the leaves, which is accompanied by their decolouring, from green to yellowish $(28,69)$. Shedding of older leaves reduces water loss and can be considered as a recycling programme within the plant, which allows reallocating stored nutrients to the younger leaves. An additional, early response to salt and drought stress is stomata closure, which also protects the plants from extensive water loss; this might result in cell dehydration, runaway xylem cavitation and even death. $(70,71)$.

\section{Physiological responses to stress}

Many reports confirm the inhibitory effects of excess salt and drought on several basic physiological and biochemical processes, of which photosynthesis is paradigmatic. The stress effects on photosynthesis can be partly assessed measuring changes in the levels of photosynthetic pigments in the stressed plants. The results of specific studies (e.g. 72-74) indicate that salinity reduces the content of chlorophylls ( $a$ and $b$ ) and carotenoids. According to Gummuluru et al. (75), chlorophyll contents and photosynthetic activity are positively correlated; therefore, reduced chlorophyll levels must contribute to the inhibition of photosynthesis that has been generally detected under abiotic stress conditions $(48,62)$. Significant decreases in chlorophyll contents as a result of salt and drought stress treatments have also been observed in many plant species, including Paulownia imperialis (76), Phaseolus vulgaris (77) and Carthamus tinctorus (78) to give only a few examples.

Chlorophyll contents in purslane accessions subjected to salt stress treatments were also reduced in parallel to the increasing external salt concentrations, although the relative reductions with respect to the non-stressed controls were maintained below $40 \%$, even at $32 \mathrm{dS} \mathrm{m}^{-1}$, the highest salinity tested (41). In plants kept under water deficit conditions, chlorophyll concentrations also declined, but only slightly $(28,79)$. This indicates that at least some Portulaca taxa are relatively resistant to drought and salt stress and could be promising candidates for commercial cultivation in arid and saline soils; they could also be used for ecosystem restoration in specific habitats affected by the effects of climate change.

Apart from affecting photosynthesis, salinity and water deficit cause profound changes in water relations in the plants, for example by reducing the osmotic potential of the leaf sap (8082). Osmotic stress, or reduced turgor pressure, especially in root cells, due to the high concentration of ions in the soil or to scarcity of water, is a common effect of salinity and drought, which causes reduced water uptake, thus inducing a cascade of effects leading to inhibition of plant growth and, eventually, to plant death $(83,84)$.

\section{Biochemical responses to salt and drought stress Ion content}

Sodium chloride is by far the most abundant salt in salinised soils worldwide. $\mathrm{Na}^{+}$and $\mathrm{Cl}^{-}$, especially $\mathrm{Na}^{+}$, are toxic at relatively low concentrations; therefore, uptake of these ions by the plant can result in cytoplasmic toxicity. Accordingly, one of the 
essential mechanisms of defence against salt stress depends on the control of ion homeostasis, by regulating the cellular uptake and transport within the plant of $\mathrm{Na}^{+}$and other toxic ions. Most plants, when growing in saline soils activate mechanisms to block transport of $\mathrm{Na}^{+}$to the shoots; such plants are defined as ' $\mathrm{Na}^{+}$excluders' (85). In contrast, some plant species accumulate high $\mathrm{Na}^{+}$concentrations in the shoots and are thus considered $\mathrm{Na}^{+}$'includers' (or 'accumulators'). The most salt-tolerant wild species, some dicotyledonous halophytes, belong to this group, as well as a few glycophytes such as barley, which is relatively resistant to salt, in comparison with other crops (86). P. oleracea also falls into this category, since salt treatments led to a significant increase of $\mathrm{Na}^{+}$concentrations in roots and leaves, which was accompanied by a parallel reduction of $\mathrm{K}^{+}$levels (79). A more recent study (87) also showed the accumulation of toxic ions $\left(\mathrm{Na}^{+}\right.$and $\left.\mathrm{Cl}^{-}\right)$in the leaves of $P$. oleracea plants under high salinity conditions.

High soil salinity interferes with plant mineral nutrition, as $\mathrm{Na}^{+}$and $\mathrm{K}^{+}$show very similar uptake mechanisms, competing for the same membrane transport systems (88). Therefore, in general, salt stress leads to an imbalance on root and leaf $\mathrm{K}^{+}$ and $\mathrm{Na}^{+}$levels; mechanisms that help to keep relatively high cellular $\mathrm{K}^{+} / \mathrm{Na}^{+}$ratios appear to be relevant for salt tolerance (89). In addition to $\mathrm{Na}^{+}$, the 'ion toxicity' component of salt stress is partly due to $\mathrm{Cl}^{-}$, the most prevalent anion under saline conditions $(85,90)$. For example, it has been reported (91) that leaf injury was associated with a high concentration of $\mathrm{Cl}^{-}$in susceptible soybean varieties; also, salt-sensitive lines of barley contained higher leaf $\mathrm{Cl}^{-}$levels than more resistant cultivars (85).

\section{Osmolytes}

Proline (Pro) accumulation has been attributed an essential role in the mechanisms of plant responses to abiotic stress, contributing in many cases to osmotic adjustment (as the only compatible solute or together with an increase in the levels of other osmolytes) and as an osmoprotectant. Free Pro is known to occur widely in higher plants, and it very often accumulates to high concentrations in response to environmental stresses (9297). In many cases, Pro accumulation has been positively correlated with stress tolerance; for example, transgenic tobacco plants over-expressing the P5CS gene - encoding the enzyme that controls the rate-limiting step of Pro biosynthesis from glutamate - show an increased Pro content and enhanced resistance to drought and salinity (98). Furthermore, Pro induces the expression of stress-responsive genes, bearing proline-responsive elements (e.g. PRE, ACTCAT) in their promoters (99-101). There are some reports describing Pro accumulation patterns in $P$. oleracea under different salinity and drought conditions, and it was found that free Pro content in leaves of purslane plants increased in response to stress, up to three-fold over control levels $(42,48,102)$.

Proline accumulation does not always correlate positively with stress tolerance in higher plants. For example, in rice plants grown under high salinity conditions, the accumulation of Pro seemed to be a symptom of injury of the leaves caused by salt rather than being a direct indicator of salt stress (103). Likewise, salt-induced increase in Pro content was not associated with tolerance in two sorghum genotypes differing in the sensitivity to salt (104). In other species, Pro accumulation correlates negatively with tolerance, with higher concentrations measured in the most sensitive genotypes, for example in different bean cultivars (105); in these cases, Pro can be considered as a reliable stress marker but is not involved in stress tolerance mechanisms.

Among the many quaternary ammonium compounds (QACs) with a functional role as compatible osmolytes in plants subjected to abiotic stress, glycine betaine (GB) occurs most abundantly in response to dehydration (106-108) and there is generally a good correlation between relative GB contents and the degree of tolerance (109). GB effectively stabilises different macromolecular structures under stress conditions, including the highly ordered cellular membranes or the quaternary structures of enzymes and other complex proteins (110). Many crop plants accumulate GB in response to stress, including sugar beet (111), spinach (112), barley (113) and sorghum (114). In these species, GB reaches typically higher concentrations in tolerant genotypes than in sensitive ones, in response to the same level of stress. However, this is not a general phenomenon, as reported for other species of Triticum, Agropyron and Elymus (90). Similarly, referring to Portulaca species, no significant differences were recorded between $P$. oleracea and P. grandiflora regarding salt-induced GB accumulation (115).

Soluble sugars can also act as physiological osmolytes in higher plants (116). According to Cram (117), in glycophytes soluble carbohydrates are the major compounds responsible for maintaining cellular osmotic balance under stress conditions, contributing up to $50 \%$ of the total osmotic potential. Soluble sugars have often been reported to accumulate in response to salinity or water deficit, even though these stresses may significantly decrease the net $\mathrm{CO}_{2}$ assimilation rate $(118,119)$. Several studies have focused on correlating changes in soluble sugar contents with the relative degree of stress tolerance. For example, soluble sugar contents increased significantly with increasing salinity in five sunflower lines differing in salt tolerance but reaching relatively higher levels in the salt-tolerant genotypes than the salt-sensitive ones (120). In contrast, this clear correlation could not be established in safflower, which showed significant differences in sugar contents between salt tolerant genotypes, while no differences were observed between some tolerant and sensitive lines (121).

\section{Oxidative stress and activation of antioxidant systems}

Many different stressful environmental conditions, including drought, high salinity, too low or too high temperatures, or heavy metals in the soil, induce, as a secondary effect, oxidative stress in plants due to the increase in the levels of 'reactive oxygen species' (ROS). ROS have multiple deleterious cellular effects, mediated by the oxidation of membrane lipids, amino acid residues in proteins and the bases in DNA $(122,123)$. 
Malondialdehyde (MDA) is a product of lipid peroxidation, generated by oxidation of membrane lipids and considered as a reliable oxidative stress marker in plants. There are many publications reporting an increase in MDA contents in response to abiotic stresses in different plant species such as turfgrass (124), sesame (125), Inula sp. (21), bitter gourd (126) or Juncus sp. (127). In salt-treated $P$. oleracea plants, a slight (14\%) increase in leaf MDA concentrations, as compared to the controls, was detected after 30 days of exposure to $140 \mathrm{mM} \mathrm{NaCl}$, whereas no significant differences between stressed and non-stressed plants were observed with shorter treatments (18 days) or lower salt concentrations (70 mM NaCl) (95). On the other hand, no increase in MDA levels was detected under water deficit conditions (48). These data are in agreement with the notion that common purslane is relatively resistant to drought and salinity.

\section{Non-enzymatic antioxidants}

Since different environmental stresses cause secondary oxidative stress in plants, a general reaction to salt and water deficit is the activation of antioxidant compounds and enzymes. Among non-enzymatic antioxidants, the complex group of phenolic compounds and, mainly, the subgroup of flavonoids, include many secondary metabolites that are apparently highly relevant for these antioxidant responses.

Phenolic compounds play multiple functional roles in plants; some are structural components of the cell walls, others are involved in the regulation of growth and different developmental processes or participate in defence reactions against herbivores and pathogens. Furthermore, many phenolics are also involved in plant responses to abiotic stresses: UV radiation, high temperature, heavy metals, herbicides, salt stress or drought, among others (128). There is evidence that these responses are mediated by the antioxidant properties of many phenolic compounds, thus explaining the increase in total phenolics contents generally observed in plants under high salinity and water deficit conditions $(129,130)$.

Flavonoids, the most complex subclass of phenolic compounds, include more than 10,000 different molecules (131) and have long been reported to be involved in a wide range of plant-environment interactions $(132,133)$. Flavonols are the most ancient and widespread subgroup of flavonoids (134); it has been proposed that they played key functions during the evolution of early terrestrial plants, as antioxidant and regulatory molecules $(135,136)$. The biosynthesis of flavonoids is upregulated not only by UV-radiation but also in response to a wide range of other abiotic (and biotic) stresses, ranging from depletion of mineral nutrients to salinity, cold or drought stress (137-139). Several studies show that flavonoid contents increase in plants upon different abiotic stress treatment, and that accumulation of these compounds correlates with the intensity of the applied stress (e.g. 140).

A study carried out on 12 different purslane accessions, including 10 ornamentals and two common purslanes (35) at increasing salinity levels $\left(0,8,16,24\right.$ and $\left.32 \mathrm{dS} \mathrm{m}^{-1}\right)$ showed that salt treatments had significant impact on total phenolics and flavonoid contents, leading to concentration-dependent increases of up to $35 \%$ over the non-stressed controls.

\section{Antioxidant enzymes}

Plants have developed a series of detoxification systems to maintain growth, development, metabolism and overall productivity under stress, avoiding or minimising the potential damage caused by ROS on cellular components $(141,142)$. Antioxidant enzymes play crucial roles as ROS scavengers in the mechanisms of defence against abiotic stress; superoxide dismutase (SOD), several peroxidases (POD), catalase (CAT) and glutathione reductase (GR) are amongst the most important antioxidant enzymatic systems, responsible for maintaining the appropriate redox equilibrium in the cell (143).

These enzymatic activities have been determined in leaves of salt-treated P. oleracea plants (102). In general, salt stress increased POD, CAT and GR specific activities, while no significant change in SOD activity was observed; however, under the strongest stress conditions tested - higher $\mathrm{NaCl}$ concentration and/or longer treatment time - some reduction of the activity with respect to the control was detected for all enzymes but GR, probably due to their inactivation. In an independent study, it was found that SOD and POD activities increased significantly in purslane plants upon drought or heat treatments, especially when both stresses were applied simultaneously (144).

A brief summary of some of the responses to salt treatments observed in three Portulaca species ( $P$. oleracea, $P$. halimoides and $P$. grandiflora), regarding inhibition of seed germination and plant growth, and changes in the levels several physiological and biochemical stress markers (chlorophylls, proline, ion contents, MDA) is shown in Table 1. For comparison, similar responses are shown for tomato, a crop that is not amongst the cultivated species most sensitive to salt.

\section{Conclusions}

Although information on Portulaca species, regarding their responses to abiotic stress, is still limited - most studies on the genus have been focused on P. oleracea, common purslane there are data indicating that some of these species are relatively resistant to drought and/or salinity. Comparative analyses of the responses to salt and water stress of closely related taxa, but with different degrees of stress resistance, represent a useful approach to investigate the mechanisms of tolerance to stress. Correlation of the activation of specific defence responses with the relative tolerance of the studied species - estimated from the relative inhibition of growth observed under controlled stress conditions and/or from the characteristics of the plants' natural habitats - will allow distinguishing the responses that are relevant for tolerance from those which are not. We propose the Portulaca genus as a suitable model to carry out this kind of studies, which can provide complementary information to that obtained from other, more common model species, thus contributing to our knowledge on the general mechanisms of abiotic stress tolerance in plants. 
Table 1. Inhibition of seed and plant growth, and changes in the levels of stress biomarkers in response to salt treatments at the indicated $\mathrm{NaCl}$ concentrations (mM), in three Portulaca species and in Solanum lycopersicum. Data for the Portulaca taxa are taken from references cited in the text; those for tomato from $(145,146,147)$

\begin{tabular}{|c|c|c|c|c|c|c|c|}
\hline \multirow[b]{2}{*}{ Species } & \multirow{2}{*}{$\begin{array}{l}\text { Seed germina- } \\
\text { tion inhibition / } \\
\mathrm{NaCl}(\mathrm{mM})\end{array}$} & \multirow{2}{*}{$\begin{array}{l}\text { Growth inhi- } \\
\text { bition / } \mathrm{NaCl} \\
(\mathrm{mM})\end{array}$} & \multirow{2}{*}{$\begin{array}{c}\text { Decrease of } \\
\text { chlorophyll } \\
\text { content / } \\
\mathrm{NaCl}(\mathrm{mM})\end{array}$} & \multirow{2}{*}{$\begin{array}{l}\text { Increase of Pro } \\
\text { content / NaCl } \\
(\mathrm{mM})\end{array}$} & \multicolumn{2}{|c|}{ Increase of ion contents } & \multirow{2}{*}{$\begin{array}{c}\text { Change in MDA } \\
\text { levels / NaCl } \\
(\mathrm{mM})\end{array}$} \\
\hline & & & & & $\begin{array}{c}\mathrm{Na}^{+} / \\
\mathrm{NaCl}(\mathrm{mM})\end{array}$ & $\mathrm{Cl}^{-} / \mathrm{NaCl}(\mathrm{mM})$ & \\
\hline P. oleracea & $50 \% / 100$ & $37 \% / 400$ & $30 \% / 400$ & $196 \% / 400$ & $1,811 \% / 400$ & $1,686 \% / 400$ & $-17 \% / 400$ \\
\hline P. halimoides & $33 \% / 100$ & $19 \% / 400$ & $14 \% / 400$ & $466 \% / 400$ & $539 \% / 400$ & $373 \% / 400$ & $-6 \% / 400$ \\
\hline P. gradiflora & $14 \% / 100$ & $12 \% / 400$ & $24 \% / 400$ & $263 \% / 400$ & $245 \% / 400$ & $141 \% / 400$ & $+14 \% / 400$ \\
\hline $\begin{array}{c}\text { Solanum } \\
\text { lycopersicum }\end{array}$ & $43 \% / 100$ & $55 \% / 200$ & $13 \% / 200$ & $88 \%$ / 150 & $98 \% / 160$ & no data & no data \\
\hline
\end{tabular}

Portulaca oleracea has been used since ancient times as a traditional Chinese medicinal plant and is a highly nutritious vegetable, very rich in antioxidant compounds and $\omega-3$ and $\omega-6$ fatty acids. On the other hand, several Portulaca species and cultivars are grown as ornamentals, mostly because of the beauty of their flowers. Due to their relative tolerance to drought and soil salinity - in comparison to our major crops these species could be developed as 'new' crops for sustainable agriculture, to be cultivated in salinised farmland, in marginal lands or arid zones, unsuitable for standard crops. They could be grown without irrigation, or using low-quality, brackish water for irrigation, and thus will (modestly) contribute to food production, apart from other economically interesting uses as medicinal plants or ornamentals. Most important, they will not compete with conventional crops for limited resources such as fertile land and good-quality irrigation water.

\section{Conflict of interest statement}

The authors declare that they have no conflict of interest.

\section{References}

1. IPCC (WGI). Climate Change 2001: The Scientific Basis. Contribution of Working Group I to the Third Assessment Report of the Intergovernmental Panel on Climate Change, JT Houghton and Ding Yihu, eds. Cambridge: Cambridge University Press, 2001.

2. IPCC (WGII). Climate Change 2001: Impacts, Adaptation, and Vulnerability. Contribution of Working Group II to the Third Assessment Report of the Intergovernmental Panel on Climate Change. JJ McCarthy, OF Canziani, NA Leary, DJ Dokken, and KS White, eds. Cambridge: Cambridge University Press, 2001b.

3. Warrick RA. The possible impacts on wheat product on of a recurrence of the 1930s drought in the U.S. Great Plans. Climatic Change 1984; 6: 5-26.

4. Boyer JS: Plant productivity and environment. Science 1982; 218(4571): 443-448.

5. Bray EA, Bailey-Serres J, Weretilnyk E. Responses to abiotic stress. In: Buchanan B, Gruissem W, Jones R eds. Biochemistry and molecular biology of plants. American Society of Plant Physiology 2000; Rockville, pp 1158-1203.

6. FAO. FAO land and plant nutrition management service 2008 . Available at http://www.fao.org/ag/agl/agll/spush

7. Wang W, Vinocur B, Altman A. Plant responses to drought, salin-

ity and extreme temperatures: towards genetic engineering for stress tolerance. Planta 2003; 218(1): 1-14.

8. Flowers TJ, Hajibagheri MA, Clipson NJW. Halophytes. Quat Rev Biol 1986; 61: 313-337. doi: 10.1086/415032

9. Zhu JK. Genetic analysis of plant salt tolerance using Arabidopsis. Plant Physiol 2000; 124: 941-948.

10. Reddy IN, Kim BK, Yoon IS, Kim KH, Kwon TR. Salt tolerance in rice: Focus on mechanisms and approaches. Rice Sci 2017; 24(3): 123144.

11. Zhang J, Zhang Y, Du Y, Chen S, Tang H. Dynamic metabonomic responses of tobacco (Nicotiana tabacum) plants to salt stress. J Proteome Res 2011; 10(4): 1904-1914.

12. Cruz V, Cuartero J. Effects of salinity at several developmental stages of six genotypes of tomato (Lycopersicon spp.). In: Proceedings of the XIth Eucarpia meeting on tomato genetics and breeding 1990: 81-86.

13. Xiong L, Zhu JK. Salt-stress signal transduction. In: Scheel D, Wasternack C, eds. Plant Signal Transduction, Frontiers in Molecular Biology Series 2002. Oxford UK: Oxford University Press, pp 165-197.

14. Zhu JK. Plant salt tolerance. Trends Plant Sci 2001; 6: 66-71.

15. Barnes RF, Baylor JE. Forages in a changing world. In: Forages, Vol 1: An introduction to Grassland Agriculture, Barnes RF, Miller DA, Nelson CJ, eds. $5^{\text {th }}$ ed. lowa State University Press, lowa 1995.

16. Rozema J, Flowers T. Crops for a salinized world. Science 2008; 322: $1478-1480$.

17. Lokhande VH, Suprasanna P. Prospects of halophytes in understanding and managing abiotic stress tolerance in environmental adaptations and stress tolerance of plants in the era of climate change, Ahmad P, Prasad MNV, eds., pp. 29-56, Springer, New York, NY, USA, 2012.

18. Ma J, Zhang M, Xiao X, You J, Wang J, Wang T, ... Tian C. Global transcriptome profiling of Salicornia europaea L. shoots under $\mathrm{NaCl}$ treatment. PloS ONE 20013; 8(6): e65877.

19. Ramani B, Reeck T, Debez A, Stelzer R, Huchzermeyer B, Schmidt A, Papenbrock J. Aster tripolium L. and Sesuvium portulacastrum L.: two halophytes, two strategies to survive in saline habitats. Plant Physiol Biochem 2006; 44(5): 395-408.

20. Zurayk RA, Baalbaki R. Inula crithmoides: a candidate plant for saline agriculture. Arid Land Res Manag 1996; 10(3): 213-223.

21. Al Hassan M, Chaura J, López-Gresa MP, Borsai O, Daniso E, Donat-Torres MP, ... Boscaiu M. Native-invasive plants vs. halophytes in Mediterranean salt marshes: Stress tolerance mechanisms in two related species. Front Plant Sci 2016; 7: 473.

22. Fita A, Rodríguez-Burruezo A, Boscaiu M, Prohens J and Vicente $O$. Breeding and domesticating crops adapted to drought and salinity: A new paradigm for increasing food production. Front Plant Sci 2015; 6: 978. 
23. Glenn EP, Anday T, Chaturvedi R, Martinez-Garcia R, Pearlstein S, Soliz D, ... Felger RS. Three halophytes for saline-water agriculture: An oilseed, a forage and a grain crop. Environ Exp Bot 2013; 92: 110-121.

24. Glenn EP, O'leary JW, Watson MC, Thompson TL, Kuehl RO. Salicornia bigelovii Torr: An oilseed halophyte for seawater irrigation. Science 1991; 251: 1065-1067. doi:10.1126/science.251.4997.1065

25. Weber DJ, Ansarib R, Gul B, Khan MA. Potential of halophytes as source of edible oil. J Arid Environ 2007; 68: 315-321. doi: 10.1016/j.jaridenv.2006.05.010

26. Ma C, Zhou D, Wang H, Han D, Wang Y, Yan X. Elicitation of Jerusalem artichoke (Helianthus tuberosus L.) cell suspension culture for enhancement of inulin production and altered degree of polymerisation. J Sci Food Agric 2017; 97(1): 88-94.

27. Khan MA, Qaiser M. Halophytes of Pakistan: characteristics, distribution and potential economic usages. Sabkha ecosystems 2006: 129-53.

28. Jin R, Wang Y, Liu R, Gou J, Chan Z. Physiological and metabolic changes of purslane (Portulaca oleracea L.) in response to drought, heat, and combined stresses. Front Plant Sci 2016; 6: 1123.

29. von Poellnitz K. Versuch eine Monographie der Gattung Portulaca L. Fedde Rep 1934; 37: 240-320.

30. Legrand D. Las especies americanas de Portulaca. Mus Hist Nat 1962; 2a Ser. 7, 1-147.

31. Geesink R. An account of the genus Portulaca in Indo-Australia and the Pacific. Blumea 1969; 17: 275-301.

32. Drummond AJ, Rambaut A. BEAST: Bayesian evolutionary analysis by sampling trees. BMC Evol Biol 2007; 7: 214. doi:10.1186/14712148-7-214.

33. Ocampo G, Columbus JT. Molecular phylogenetics, historical biogeography, and chromosome number evolution of Portulaca (Portulacaceae). Mol Phylogenetics Evol 2016; 63(1): 97-112.

34. Teixeira M, Carvalho IS. Effects of salt stress on purslane (Portulaca oleracea) nutrition. Ann App Bio 2009; 154(1): 77-86.

35. Alam MA, Juraimi AS, Rafii MY, Abdul Hamid A, Aslani F. Screening of purslane (Portulaca oleracea L.) accessions for high salt tolerance. Sci World J 2014; 9.

36. Grieve CM, Suarez DL. Purslane (Portulaca oleracea L.): a halophytic crop for drainage water reuse systems. Plant and Soil 1997; 192(2): 277-283.

37. Ren S, Weeda S, Akande O, Guo Y, Rutto L, Mebrahtu T. Drought tolerance and AFLP-based genetic diversity in purslane (Portulaca oleracea L.). J Biotech Res 2011; 3: 51-61.

38. Liu L, Howe P, Zhou YF, Hocart C, Zhang R. Fatty acid profiles of leaves of nine edible wild plants: an Australian study. J Food Lipids 2002; 9: 65-71.

39. Zheng ZH, Dong ZH, Yu J. Modern study of traditional Chinese medicine, Xue Yuan Press, Beijing University of Traditional Chinese Medicine, Beijing, 1997.

40. Simpoulos AP. Omega-3 fatty acids in health and disease and in growth and development. Am J Clin Nutr 1991; 54: 438-463.

41. Alam MA, Juraimi AS, Rafii MY, Hamid AA, Aslani F, Alam MZ. Effects of salinity and salinity-induced augmented bioactive compounds in purslane (Portulaca oleracea L.) for possible economical use. Food Chem 2015; 169: 439-447.

42. Mulry KR, Hanson BA, Dudle DA. Alternative strategies in response to saline stress in two varieties of Portulaca oleracea (purslane). PloS ONE 2015; 10(9): e0138723.

43. Crane TA, Roncoli C, Hoogenboom G. Adaptation to climate change and climate variability: the importance of understanding agriculture as performance. NJAS -Wag. J Life Sci 2011; 57: 179185. doi: 10.1016/j.njas.2010.11.002

44. Gill SS, Tuteja N. Reactive oxygen species and antioxidant machinery in abiotic stress tolerance in crop plants. Plant Physiol Biochem 2010; 48(12): 909-930.

45. Wang W, Vinocur B, Altman A. Plant responses to drought, salinity and extreme temperatures: towards genetic engineering for stress tolerance. Planta 2003; 218(1): 1-14.
46. Hilker M, Schwachtje J, Baier M, Balazadeh S, Bäurle I, Geiselhardt $S$... Kopka J. Priming and memory of stress responses in organisms lacking a nervous system. Biol Rev 2015; 91: 1118-1133. doi: $10.1111 /$ brv. 12215

47. Vicente $\mathrm{O}$, Boscaiu M, Naranjo MA, Estrelles E, Bellés JM, Soriano P. Responses to salt stress in the halophyte Plantago crassifolia (Plantaginaceae). J Arid Environ 2004; 58: 463-481.

48. Rahdari P, Tavakoli S, Hosseini SM. Studying of salinity stress effect on germination, proline, sugar, protein, lipid and chlorophyll content in purslane (Portulaca oleracea L.) leaves. J Stress Physiol Biochem 2012; 8(1): 182-193.

49. Borsai O, Al Hassan M, Boscaiu M, Vicente O, Sestras A, Sestras R. Effects of salt on seed germination and seedling growth of three Portulaca species. Bulletin USAMV Cluj-Napoca. Horticulture 2015; 72(2): 450-451.

50. Franco JA, Cros V, Vicente MJ, Martínez-Sánchez JJ. Effects of salinity on the germination, growth, and nitrate contents of purslane (Portulaca oleracea L.) cultivated under different climatic conditions. J Hortic Sci Biotechnol 2011; 86(1): 1-6.

51. Rahimi Z, Kafi M. Effects of drought stress on germination characteristics of purslane (Portulaca oleracea L.). Environ Stress Crop Sci 2009; 2(1): 87-91.

52. Pill WG, Frett JJ, Morneau DC. Germination and seedling emergence of primed tomato and asparagus seeds under adverse conditions. Hort Sci 1991; 26(9): 1160-1162.

53. Miceli A, Moncada A, D'Anna F. Effect of water salinity on seeds germination of Ocimum basilicum L., Eruca sativa L. and Petroselinum hortense Hoffm. Acta Hort 2003; 609: 365-370.

54. Zapryanova N, Atanassova B. Effects of salt stress on growth and flowering of ornamental annual species. Biotechnol Biotechnol Equip 2009; 23(sup1): 177-179.

55. Cicevan R, Al Hassan M, Sestras AF, Prohens J, Vicente O, Sestras $\mathrm{RE}$, Boscaiu M. Screening for drought tolerance in cultivars of the ornamental genus Tagetes (Asteraceae). Peer J 2016; 4: e2133.

56. Jaleel PM, Wahid A, Farooq M, Al-Juburi HJ, Somasundaram R, Vam RP. Drought stress in plants: a review on morphological characteristics and pigments composition Int J Agric Biol 2009; 11: 100-105.

57. Kaya MD, Okçu G, Atak M, Çıkılı Y, Kolsarıcı Ö. Seed treatments to overcome salt and drought stress during germination in sunflower (Helianthus annuus L.). Eur J Agron 2006; 24(4): 291-295.

58. Giménez Luque E, Delgado Fernández IC, Gómez Mercado F. Effect of salinity and temperature on seed germination in Limonium cossonianum. Botany 2012; 91(1): 12-16.

59. Al Hassan M, Estrelles E, Soriano P, López-Gresa MP, Bellés JM, Boscaiu $\mathrm{M}$, Vicente $\mathrm{O}$. Unraveling salt tolerance mechanisms in halophytes: a comparative study on four Mediterranean Limonium species with different geographic distribution patterns. Front Plant Sci 2017; 8:1438. doi: 10.3389/fpls.2017.01438

60. Sharma P, Jha AB, Dubey RS, Pessarakli M. Reactive oxygen species, oxidative damage, and antioxidative defense mechanism in plants under stressful conditions. J Bot 2012. doi: 10.1155/2012/217037

61. Serrano R, Mulet JM, Rios G, Marquez JA, Larrinoa IF, Leube MP, Mendizabal I, Pascual-Ahuir A, Proft M, Ros R, Montesinos C. A glimpse of the mechanisms of ion homeostasis during salt stress. J Exper Bot 1999; 50: 1023-1036.

62. Yan K, Shao H, Shao C, Chen P, Zhao S, Brestic M, Chen X. Physiological adaptive mechanisms of plants grown in saline soil and implications for sustainable saline agriculture in coastal zone. Acta Physiol Plant 2013; 35(10): 2867-2878.

63. Nakabayashi R, Mori T, Saito K. Alternation of flavonoid accumulation under drought stress in Arabidopsis thaliana. Plant Signal Behav 2014; pii: e29518.

64. Alam MA, Juraimi, AS, Rafii MY, Hamid AA, Aslani F, Hakim MA. Salinity induced changes in the morphology and major mineral nutrient composition of purslane (Portulaca oleracea L.) accessions. Biol Res 2016; 49: 24. doi: 10.1186/s40659-016-0084-5

65. van Zandt PA, Mopper S. Delayed and carry over effects of salinity on flowering in Iris hexagona (Iridaceae). Am J Bot 2002; 89(11): 
1847-1851.

66. Boyd RS, Barbour MG. Relative salt tolerance of Cakile edentuIa (Brassicaceae) from lacustrine and marine beaches. Am J Bot 1986; 73(2): 236-241.

67. Blits KC, Gallagher JL. Morphological and physiological responses to increased salinity in marsh and dune ecotypes of Sporobolus virginicus (L.). Kunth Oecologia 1991; 87(3): 330-335.

68. Ludlow MM, Ng TT. Water stress suspends leaf ageing. Plant Sci Lett 1974; 3: 235-240.

69. Amirul Alam M, Shukor A, Rafii JMY, Hamid AA, Uddin MK, Alam MZ, Latif MA. Genetic improvement of purslane (Portulaca oleracea L.) and its future prospects Mol Biol Rep 2014; 41: 7395-7411. doi 10.1007/s11033-014-3628-1

70. Schulze ED. Whole-plant responses to drought. Aust J Plant Physiol 1986; 13: 127-141.

71. Chaves MM, Flexas J, Pinheiro C. Photosynthesis under drought and salt stress: regulation mechanisms from whole plant to cell. Ann Bot 2009; 103(4): 551-560.

72. Qados AMA. Effect of salt stress on plant growth and metabolism of bean plant Vicia faba (L.). Journal of the Saudi Society of Agricultural Sciences 2011; 10(1): 7-15.

73. Misra AN, Latowski D and Strzalka K. The xanthophyll cycle activity in kidney bean and cabbage leaves under salinity stress. Russ J Plant Physiol 2006; 53(1): 102-109.

74. Murillo-Amador B, Yamada S, Yamaguchi T, Rueda-Puente E, Ávila-Serrano N, García-Hernández JL, Nieto-Garibay A. Influence of calcium silicate on growth, physiological parameters and mineral nutrition in two legume species under salt stress. J Agron Crop Sci 2007; 193(6): 413-421.

75. Gummuluru S, Jana S, Hobbs S. Genotypic variability in physiological characters and its relationship to drought tolerance in durum wheat. Can. J. Plant Sci 1989; 69(3): 703-711.

76. Ayala-Astorga Gl, Alcaraz-Meléndez L. Salinity effects on protein content, lipid peroxidation, pigments, and proline in Paulownia imperialis (Siebold \& Zuccarini) and Paulownia fortunei (Seemann \& Hemsley) grown in vitro. Electron J Biotechnol 2010; 13(5): 13 14.

77. Beinsan C, Camen D, Sumalan R, Babau M. Study concerning salt stress effect on leaf area dynamics and chlorophyll content in four bean local landraces from Banat area. Fac Hortic 2003; 119: 416419.

78. Siddiqi EH, Ashraf M, Hussain M, Jamil A. Assessment of intercultivar variation for salt tolerance in safflower (Carthamus tinctorius L.) using gas exchange characteristics as selection criteria. Pak J Bot 2009; 41(5): 2251-2259.

79. Kafi M, Rahimi Z. Effect of salinity and silicon on root characteristics, growth, water status, proline content and ion accumulation of purslane (Portulaca oleracea L.). J Soil Sci Plant Nutr 2011; 57(2): 341-347.

80. Rodriguez P, Dell'Amico J, Morales D, Blanco MS, Alarcón JJ. Effects of salinity on growth, shoot water relations and root hydraulic conductivity in tomato plants. J Agric Sci 1997; 128(4): 439-444.

81. Gama PBS, Inanaga S, Tanaka K, Nakazawa R. Physiological response of common bean (Phaseolus vulgaris L.) seedlings to salinity stress. Afr J Biotechnol 2007; 6(2): 79-88.

82. Gama PBS, Tanaka K, Eneji AE, Eltayeb AE, Siddig KE. Salt-induced stress effects on biomass, photosynthetic rate, and reactive oxygen species-scavenging enzyme accumulation in common bean. J Plant Nut 2009; 32(5): 837-854.

83. Munns R. Physiological processes limiting plant growth in saline salt: some dogmas and hypotheses. Plant Cell Environ 1993; 16 15-24.

84. Li Z, Wakao S, Fischer BB, Niyogi KK. Sensing and responding to excess light. Annu Rev Plant Biol 2009; 60: 239-260. doi: 10.1016/j. cub.2005.06.041.

85. Greenway H, Munns R. Mechanisms of salt tolerance in nonhalophytes. Annu Rev Plant Physiol 1980; 31(1): 149-190.

86. Collander R. Selective absorption of cations by higher plants
Plant Physiol 1941; 16(4): 691-720.

87. Karakaş S, Cullu MA, Dikilitaş M. Comparison of two halophyte species (Salsola soda and Portulaca oleracea) for salt removal potential under different soil salinity conditions. Turk J Agric For, 2017; 41(3): 183-190.

88. Niu X, Bressan RA, Hasegawa PM, Pardo JM. Ion homeostasis in $\mathrm{NaCl}$ stress environments. Plant Physiol 1995; 109: 735-742.

89. Maathuis FJM, Amtmann A. $\mathrm{K}^{+}$nutrition and $\mathrm{Na}^{+}$toxicity: The basis of cellular K+/ $\mathrm{Na}^{+}$ratios. Ann Bot. 1999; 84: 123-133.

90. Gorham J, Hughes LL, Wyn Jones RG. Low-molecular-weight carbohydrates in some salt-stressed plants. Physiol Plant 1981; 53(1): 27-33.

91. Abel GH, MacKenzie AJ. Salt tolerance of soybean varieties (Glycine max L. Merrill) during germination and later growth. Crop Sci 1964; 4(2): 157-161.

92. Rains DW. Plant tissue and protoplast culture: applications to stress physiology and biochemistry. In: Jones HG, Flowers TJ, Jones MB, eds. Plants Under Stress: Biochemistry, Physiology and Ecology and Their Application to Plant Improvement 1989; Seminar Series 39: 181-196.

93. Ali G, Srivastava PS, Iqbal M. Proline accumulation, protein pattern and photosynthesis in regenerants grown under $\mathrm{NaCl}$ stress. Biol Plant 1999; 42: 89-95.

94. Rhodes D, Verslues PE, Sharp RE. Role of amino acids in abiotic stress resistance. In: Singh BK, ed., Plant Amino Acids: Biochemistry and Biotechnology. Marcel Dekker, NY 1999; 319-356.

95. Ozturk L, Demir Y. In vivo and in vitro protective role of proline. Plant Growth Regul 2002; 38: 259-264.

96. Hsu SY, Hsu YT, Kao CH. The effect of polyethylene glycol on proline accumulation in rice leaves. Biol Plant 2003; 46: 73-78.

97. Kavi Kishore PB, Sangam S, Amrutha RN, Laxmi PS, Naidu KR, Rao KRSS, Rao S, Reddy KJ, Theriappan P, Sreenivasulu N. Regulation of proline biosynthesis, degradation, uptake and transport in higher plants: its implications in plant growth and abiotic stress tolerance. Curr Sci 2005; 88: 424-438.

98. Kishor PBK, Hong Z, Miao GH, Hu CAA, Verma DPS. Over-expression of [delta]-pyrroline-5-carboxylate synthetase increases proline production and confers osmotolerance in transgenic plants. Plant Physiol 1995; 108: 1387-1394.

99. Satoh R, Nakashima K, Seki M, Shinozaki K, Yamaguchi-Shinozaki K. 2002. ACTCAT, a novel cis-acting element for proline- and hypoosmolarity-responsive expression of the ProDH gene encoding proline dehydrogenase in Arabidopsis. Plant Physiol 2002; 130: 709-719.

100. Oono Y, Ooura C, Rahman A, Aspuria ET, Hayashi K, Tanaka A, Uchimiya H. P-clorophenoxyisobutyric acid impairs auxin response in Arabidopsis root. Plant Physiol 2003; 133: 1135-1147.

101. Chinnusamy V, Jagendorf A, Zhu JK. Understanding and improving salt tolerance in plants. Crop Sci 2005; 45: 437-448.

102. Yazici I, Türkan I, Sekmen AH, Demiral T. Salinity tolerance of purslane (Portulaca oleracea L.) is achieved by enhanced antioxidative system, lower level of lipid peroxidation and proline accumulation. Environ Exp Bot 2007; 61(1): 49-57.

103. Lutts S, Majerus V, Kinet JM. NaCl effects on proline metabolism in rice (Oryza sativa) seedlings. Physiol Plant 1999; 105: 450-458.

104. Lacerda CFD, Cambraia J, Oliva MA, Ruiz HA. Osmotic adjustment in roots and leaves of two sorghum genotypes under $\mathrm{NaCl}$ stress. Braz J Plant Physiol 2003; 15(2): 113-118.

105. Al Hassan M, Morosan M, López-Gresa MP, Prohens J, Vicente O, Boscaiu M. Salinity-induced variation in biochemical markers provides insight into the mechanisms of salt tolerance in common (Phaseolus vulgaris) and runner (P. coccineus) beans. Int J Mol Sci 2016; 17: 1582. doi:10.3390/ijms17091582

106. Venkatesan A, Chellappan KP. Accumulation of proline and glycine betaine in Ipomoea pes-caprae induced by $\mathrm{NaCl}$. Biol Plant 1998; 41: 271-276. doi:10.1023/A:1001839302627

107. Mansour MMF. Nitrogen containing compounds and adaptation of plants to salinity stress. Biol Plant 2000; 43: 491-500. doi: 


\subsection{3/A:1002873531707}

108. Mohanty A, Kathuria H, Ferjani A, Sakamoto A, Mohanty P, Murata $\mathrm{N}$, Tyagi AK. Transgenics of an elite indica rice variety pusa basmati 1 harbouring the coda gene are highly tolerant to salt stress. The or Appl Genet 2002; 106: 51-57. doi:10.1007/s00122- 002-1063-5

109. Rhodes D, Hanson AD. Quaternary ammonium and tertiary sulfonium compounds in higher plants. Annu Rev Plant Physiol Plant Mol Biol 1993; 44: 357-384.

110. Papageorgiou GC, Murata N. The unusually strong stabilizing effects of glycinebetaine on the structure and function of the oxygen-evolving photosystem II complex. Photosynth Res 1995; 44: 243-252.

111. Shaw B, Thomas TH, Cooke DT. Responses of sugar beet (Beta vulgaris L.) to drought and nutrient deficiency stress. Plant Growth Reg 2002; 37(1): 77-83.

112. Di Martino C, Delfine S, Pizzuto R, Loreto F, Fuggi A. Free amino acids and glycine betaine in leaf osmoregulation of spinach responding to increasing salt stress. New Phytol 2003; 158(3): 455463.

113. Ishitani M, Nakamura T, Han SY, Takabe T. Expression of the betaine aldehyde dehydrogenase gene in barley in response to osmotic stress and abscisic acid. Plant Mol Biol 1995; 27: 307-315.

114. Weimberg R, Lerner HR, Poljakoffmayber A. Changes in growth and water soluble solute concentrations in Sorghum bicolor stressed with sodium and potassium salts. Physiol Plant 1984; 62: 472-480. doi:10.1111/j.1399-3054.1984.tb04605.x

115. Nishimura N, Zhang J, Abo M, Okubo A, Yamazaki S. Application of capillary electrophoresis to the simultaneous determination of betaines in plants. Anal Sci 2001; 17(1): 103-106.

116. Gil R, Boscaiu M, Lull C, Bautista I, Lidón A, Vicente O. Are soluble carbohydrates ecologically relevant for salt tolerance in halophytes? Funct. Plant Biol 2013; 40: 805-818.

117. Cram WJ. Negative feedback regulation of transport in cells. The maintenance of turgor, volume and nutrient supply. In: Luttge $U_{\text {, }}$ Pitman MG, eds. Encyclopaedia of Plant Physiology, New Series, Springer-Verlag, Berlin 1976; 2: 284-316.

118. Popp N, Smirnoff N. Polyol accumulation and metabolism during water deficit. In: Smirnoff N, ed., Environment and Plant Metabolism: Flexibility and Acclimation, Bios Scientific, Oxford 1995; 199215.

119. Murakeozy EP, Nagy Z, Duhaze C, Bouchereau A, Tuba Z. Seasonal changes in the levels of compatible osmolytes in three halophytic species of inland saline vegetation in Hungary. J Plant Physiol 2003; 160: 395-401.

120. Ashraf M, Tufail M. Variation in salinity tolerance in sunflower (Helianthus annuus L.), J Agron Soil Sci 1995; 174: 351-362.

121. Ashraf $M$, Fatima $H$. Responses of some salt tolerant and salt sensitive lines of safflower (Carthamus tinctorius L.). Acta Physiol Plant 1995; 17: 61-71.

122. Alscher, RG, Erturk N, Heath LS. Role of superoxide dismutases (SODs) in controlling oxidative stress in plants. J Exp Bot 2002 53(372): 1331-1341.

123. Mittler R. Abiotic stress, the field environment and stress combination. Trends Plant Sci 2006; 11: 15-19.

124. Xu S, Li J, Zhang X, Wei H, Cui L. Effects of heat acclimation pretreatment on changes of membrane lipid peroxidation, antioxidant metabolites, and ultrastructure of chloroplasts in two cool-season turfgrass species under heat stress. Environ Exp Bot 2006; 56: 274-285.

125. Koca M, Bor M, Ozdemir F, Turkan I. The effect of salt stress on lipid peroxidation, antioxidative enzymes and proline content of sesame cultivars. Environ Exp Bot 2007; 60: 344-351.

126. Agarwal S, Shaheen R. Stimulation of antioxidant system and lipid peroxidation by abiotic stresses in leaves of Momordica charantia. Braz J Plant Physiol 2007; 19(2): 149-161.

127. Al Hassan M, Chaura J, Donat-Torres MP, Boscaiu M, Vicente O. Antioxidant responses under salinity and drought in three closely re- lated wild monocots with different ecological optima. AoB Plants 2017; 9(2). doi:10.1093/aobpla/plx009.

128. Gould KS, Lister C. Flavonoid function in plants. In: Andersen $\varnothing \mathrm{M}$ Marham KR, eds. Flavonoids, Chemistry, Biochemistry and Application, CRC Press, Boca Raton, FL, 2006; 397-442.

129. Akula $R$, Ravishankar GA. Influence of abiotic stress signals on secondary metabolites in plants. Plant Signal Behav 2011; 6(11): 1720-1731.

130. Waśkiewicz A, Muzolf-Panek M, Goliński P. Phenolic content changes in plants under salt stress. In: Ahmad P, Azooz MM, Prasad MNV, eds. Ecophysiology and responses of plants under salt stress. Springer 2013.

131. Harborne JB, Williams CA. Advances in flavonoid research since 1992. Phytochemistry 2000; 55(6): 481-504.

132. Winkel-Shirley B. Biosynthesis of flavonoids and effect of stress. Curr Opin Plant Biol 2002; 5: 218-223. doi: 10.1016/S13695266(02) 00256-X

133. Agati G, Tattini M. Multiple functional roles of flavonoids in photoprotecion. New Phytol 2010; 186: 786-793.

134. Rausher MD. The evolution of flavonoids and their genes. In: The science of flavonoids. Springer New York 2006; 175-211.

135. Swain T, The evolution of flavonoids. In: Plant Flavonoids in Biology and Medicine, Buffalo, New York (USA) 1986.

136. Stafford HA. Flavonoid evolution: an enzymic approach. Plant Physiol 1991; 96(3): 680-685.

137. Tattini M, Galardi C, Pinelli P, Massai R, Remorini D, Agati G. Differential accumulation of flavonoids and hydroxycinnamates in leaves of Ligustrum vulgare under excess light and drought stress. New Phytol 2004; 163: 547-561.

138. Lillo C, Lea US, Ruoff P. Nutrient depletion as a key factor for manipulating gene expression and product formation in different branches of the flavonoid pathway. Plant Cell Environ 2008; 31: 587-601.

139. Agati G, Biricolti S, Guidi L, Ferrini F, Fini A, Tattini M. The biosynthesis of flavonoids is enhanced by UV radiation and root zone salinity in L vulgare leaves, J Plant Physiol 2011; 168: 204-212

140. Rivero RM, Ruiz JM, Garcia PC, Lopez-Lefebre LR, Sánchez E, Romero L. Resistance to cold and heat stress: accumulation of phenolic compounds in tomato and watermelon plants. Plant Sci 2001; 160(2): 315-321.

141. Larkindale J, Huang B. Thermo-tolerance and antioxidant systems in Agrostis stoloifera: involvement of salicylic acid, abscisic acid, calcium, hydrogen peroxide, and ethylene. J Plant Physiol 2004; 161: 405-413.

142. Mittler R. Oxidative stress, antioxidants and stress tolerance. Trends Plant Sci 2002; 7: 405-410.

143. Naya L, Ladrera R, Ramos J, Gonzalez EM, Arrese-Igor C, Minchin FR, Becana M. The response of carbon metabolism and antioxidant defenses of alfalfa nodules to drought stress and to the subsequent recovery of plants. Plant Physiol 2017; 144: 1104-1114. doi 10.1104/pp.107.099648

144. Jin R, Wang Y, Liu R, Gou J, Chan Z. Physiological and metabolic changes of purslane (Portulaca oleracea L.) in response to drought, heat, and combined stresses. Front Plant Sci 2015; 6: 1123. doi: 10.3389/fpls.2015.01123

145. Bologa M, Jităreanu CD, Slabu C, Marta AE. Salinity Stress Effects on the Growing Rates of Tomato (Lycopersicon esculentum Mill.). Bulletin USAMV series Agriculture 2015; 72(1): 277-278.

146. Gharsallah C, Fakhfakh H, Grubb D, Gorsane F. Effect of salt stress on ion concentration, proline content, antioxidant enzyme activities and gene expression in tomato cultivars. AoB Plants. 2016; 8. doi: 10.1093/aobpla/plw055.

147. Amini F, Ehsanpour AA. Soluble proteins, proline, carbohydrates and $\mathrm{Na}+/ \mathrm{K}+$ changes in two tomato (Lycopersicon esculentum Mill.) cultivars under in vitro salt stress. Am J Biochem Biotechnol 2005; 1(4): 204-208. 